\title{
A Proposed Restricting Of Lebanese Public Debt To Promote Economic Growth
}

\author{
Viviane Y. Naïmy, (E-mail: vnaimy@ndu.edu.lb) Notre Dame University, Lebanon
}

\begin{abstract}
The Lebanese economy is subjected to major constraints impeding its growth and its development. Public overborrowing constitutes the main obstacle against this growth. The Lebanese economic situation is briefly presented in this paper. Then, a measurement of the Lebanese public debt dangers is proposed through an econometric model illustrating the snowball effects. After an analysis, a simulation aiming at restructuring this debt, with a valuation of the foreign indebtedness' limits, is presented.
\end{abstract}

\section{Introduction}

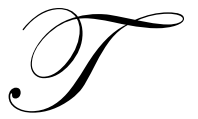

he Lebanese financial system, mainly constituted of the banking system, is subjected to major constraints impeding its economic growth. The budget and fiscal policies followed in recent decades have generated an unbearable public debt. The financing of the budget deficit was ensured, since 1992, via the accumulation of an increasing public debt, contracted at very high interest rates. Consequently, the service of this debt becomes prohibitive in an unfavorable macroeconomic context where paradoxical government choices have been applied and were largely illustrated by the fixity of the exchange rate ${ }^{1}$ and by a periodical upward pressure on interest rates.

The coexistence of a budget deficit in continuous progression with very high interest rate levels carried the public debt servicing to a point of no return (since 1995, the debt service exceeded $80 \%$ of the public revenues). In the contemporary economic language, this phenomenon is called the snowball effect.

This study proposes a recapitulation of the Lebanese economic situation, followed by an analysis of the Lebanese public debt aiming at measuring the dangers and the consequences of the snowball effects.

Beyond the Lebanese specificities, the overborrowing situation of this country has become a consistent "academic case" allowing the illustration of the snowball phenomenon and its consequences. Therefore, the main issue of this paper aims not only at proposing several leads and approaches related to the Lebanese snowball effect but also at making this paper useful and practical for studying other Third World Countries' public debts.

\section{The Present Economic Situation}

\subsection{Administrative Shortcomings}

Bad administrative management plays a major role in restricting solutions for socio-economic crises. Indeed, Public Administration in Lebanon suffers from mediocrity in terms of productivity, efficiency, leadership, let alone disguised unemployment, absence of statistics, incompetent recruitment, etc. These handicaps and similar others lead, inevitably, to an administration that is over costly and ends up with big budgetary burden unaffordable by the present Lebanese economy.

\footnotetext{
1 The Lebanese Pound expressed in USD: 1 dollar = 1500 Lebanese Pounds.
} 
The Administration recruits $20 \%$ of the productive forces in the country as compared to $2 \%$ recruited by the banking sector. While as the $2 \%$ in terms of productivity equals the $20 \%$ if not more.

The question however is not only administrative, but reflects the political life of the country, greatly based on familial and confessional differences, and divisions which impedes the development of a modern State, in which the rule of citizenship dominates.

\subsection{Costly Reconstruction}

Lebanon, despite the fact that it has considerably progressed in terms of reconstruction and infrastructure, presents a real decrease in the production level compared with its potential resources. This has been negatively reflected on individual revenues, internal consumption capacity, and output levels of the economy. A sound economic policy that aims at ensuring social justice is supposed to promote production, optimize the use of natural resources capable to expand productive bases, reduce the balance of payment's deficit, create employment opportunities, and initiate an economic growth congruent with a social development objective.

Development projects in Lebanon, registered under the label of reconstruction, have been noticeably distracted from the above-mentioned strategies. In fact, they have been financed by external loans on short-term basis and at commercial interest rates. These projects however are still incomplete. They have been vitiated by abnormal high costs and bribes, knowing that tenders were often concluded by mutual agreement instead of legal competition.

Given that the profitability of these projects is for long term, the reimbursement of loans has been done through new loans. This has discredited the official feasibility studies and increased the general $\mathrm{debt}^{2}$ that has jumped from 2.5 billion dollars in 1992 to 19.47 billions in 1998 and to 22.3 billion dollars in 1999 ending up with 31.5 billions for 2002 .

Therefore, the impact of public expenses on the social and economic life is minor. Public funds have been consumed without stimulating the business cycle, or improving social development and national prosperity. De facto, the budget deficit is largely responsible for the financial crisis: deficit to total expenses reached $85 \%$ in 1990 , $61 \%$ in 1997, has passed to $44 \%$ in 1999, and exceeded $45 \%$ in 2002.

\subsection{An Economy That Serves Its Currency}

Viewed from this angle, the current monetary fixity - obtained at this prohibitive cost - is not really a panacea. Actually, high interest rate policy, represented by the budget category called " public debt service", which is currently at $80 \%$ of the total budget revenue, have impoverished the country, reduced productive investments, transformed the whole national economy into a rent economy and failed to make of the national currency a real reserve currency ${ }^{3}$. The Lebanese Pound is not anymore used as a currency for loan ${ }^{4}$, because the majority ${ }^{5}$ of credits granted to private sectors are made in foreign currency. Therefore, the present confidence in the Lebanese Pound isn't but temporary, since it is based on return generated ${ }^{6}$ not on conviction. Only a policy aiming at rebuilding the economy is likely to reinforce, on a permanent basis, the Lebanese currency.

The growth of the Lebanese economy - or more precisely, that of the national revenue - is found to have slowed down since 1994. It is characterized by a drop in the level of production and revenue and, conversely, in a progress in the level of rents and taxes. The result was a big concentration of capital movements, as a consequence of profits that capital holders have drawn from the present rent economy. Only one percent of Lebanese account

2 Lebanese Banks Association: Annual reports 1998-1999-2000-2001-2-3.

$65 \%$ of the total banking deposits in average are denominated in US dollar not in Lebanese Pound.

i.e. private loans allocated to finance private corporations and other productive projects.

$584 \%$ of loans allocated for the private sector in 2002 were made in USD.

6 Most of investors (constituted mainly of commercial banks) subscribe their funds in Treasury Bonds issued in Lebanese Pounds because Treasury Bonds represent the most attractive assets to invest in and offer the highest possible interest (interest rates served on TB's averaged $25 \%$ from 1993 to 2001). 
holders have $40 \%$ of the whole banking deposits as compared to $2 \%$ of borrowers who benefit of $66 \%$ of available funds for credit purposes ${ }^{7}$.

Altogether, this fixity policy is neither encouraging the full use of the available resources nor contributing to the mobilization of human capital in the improvement of labor skills.

\subsection{Fiscal Inequality}

Fiscal inequality is obvious and harmful in Lebanon. Therefore, reforming the Lebanese fiscal system should be radical and following economic and social specific criteria. In other terms, the reform ${ }^{8}$ should aim at making this system more receptive to economic recovery and more socially equitable. In fact, the distribution of revenue shows a critical increase of social inequalities. Added to all this, third of the country's population is displaced ${ }^{9}$.

\subsection{Low Return On Investment}

Return on investment in the private sector is hampered by the high return generated from Lebanese Treasury bonds. Since 1995, Lebanon is suffering from a severe crowd-out effect. Consequently, supportive infrastructure for a better production ${ }^{10}$ has been completely neglected.

\section{Public Overborrowing And Snowball Effect}

The problem of budget deficit and of public indebtedness appeared with the starting of the civil war ${ }^{11}$ in Lebanon. In fact, public revenues, before 1975, were equivalent, even higher than public expenditures. Until the end of 1992, the public deficit was often counterbalanced by loans granted by the Lebanese Central Bank. This had deeply contributed to the rise of the inflation rate and to the deterioration of the exchange rate of the Lebanese Pound against the US dollar.

Starting 1993, a currency exchange fixity policy was adopted. This policy consisted of fixing the Lebanese Pound against the US dollar ${ }^{12}$ and even progressively to improving this rate. The financing of the budget deficit by the Lebanese Central Bank was then stopped to be limited to financial institutions ${ }^{13}$ and to the public.

This plan was accompanied by a strongly expansionist budget policy that went on until 1998 and that generated a rise in public expenditures (between 1993 and 1997) to a real average ${ }^{14}$ rate of $22.4 \%$ a year, against a rate of $9.6 \%$ for revenues. As a result, the budget deficit rose to the GDP, moving from $9.3 \%$ in 1993 to $26 \%$ in 1997 and 18\% in 2001. Parallel to this rise, public indebtedness increased very quickly, moving from 52\% of the GDP in 1993, to $103 \%$ in 1997. In 2000, it rose to $147 \%$ of the GDP to reach $182 \%$ in 2002.

\footnotetext{
7 Yachoui E., (1998). Working paper presented during a conference on the Lebanese Economy « Les Déboires de l'Economie Nationale ».

8 This restructuring presupposes firm political and social choices such as: fighting illicit enrichment, increasing public revenues and reducing the budget deficit. The increase of revenue levels is dependent, in the case of Lebanon, on two imperatives: the first consists of the personalization of taxes based on real revenues of taxpayers, and the second deals with inspecting productivity gains and enhancing collection procedures.

9 Report of «Fonds National des déplacés » (1998)

${ }_{10}$ Such as the promotion of industrial zones equipments, the increase of cultivated and irrigated surfaces, the support of labor forces (training, preparing, educating, etc.), and so forth.

11 In 1975

12 Presently 1 dollar $=1500$ Lebanese Pounds.

13 Mainly constituted of commercial banks.

${ }^{14}$ Calculated at constant prices.
} 
Table 1- Public Finance Situation (in billion LP)

\begin{tabular}{|l|c|c|c|c|c|c|c|c|c|c|}
\hline & $\mathbf{1 9 9 3}$ & $\mathbf{1 9 9 4}$ & $\mathbf{1 9 9 5}$ & $\mathbf{1 9 9 6}$ & $\mathbf{1 9 9 7}$ & $\mathbf{1 9 9 8}$ & $\mathbf{1 9 9 9}$ & $\mathbf{2 0 0 0}$ & $\mathbf{2 0 0 1}$ & $\mathbf{2 0 0 2} * *$ \\
\hline Overall revenues & 1855 & 2241 & 3033 & 3533 & 3753 & 4449 & 4868 & 4552 & 4650 & 4335 \\
\hline $\begin{array}{l}\text { Global } \\
\text { expenditure }\end{array}$ & 3069 & 5379 & 6342 & 7732 & 9662 & 8385 & 8910 & 10684 & 9138 & 7195 \\
\hline $\begin{array}{l}\text { Including debt } \\
\text { service }\end{array}$ & 784 & 1488 & 1875 & 2653 & 3378 & 3352 & 3624 & 4197 & 4312 & 3251 \\
\hline Public deficit & 1214 & 3138 & 3309 & 4199 & 5909 & 3936 & 4042 & 6132 & 4488 & 2860 \\
\hline $\begin{array}{l}\text { Global public } \\
\text { debt at the end of } \\
\text { period }\end{array}$ & 6648 & 10779 & 14155 & 20189 & 23501 & $29213 *$ & 33732 & 37643 & 42723 & 46650 \\
\hline GDP & 13122 & 15305 & 18028 & 20417 & 22880 & 24509 & 24816 & 24816 & 25188 & 26700 \\
\hline Deficit / GDP (\%) & 9,25 & 20,50 & 18,35 & 20,57 & 25,83 & 16,06 & 16,29 & 24.7 & 18 & \\
\hline $\begin{array}{l}\text { Public debt / GDP } \\
\text { (\%) }\end{array}$ & 50,66 & 70,43 & 78,52 & 98,88 & 102,71 & 119,19 & 136 & 151.7 & 170.5 & $182 * * *$ \\
\hline $\begin{array}{l}\text { Debt service / } \\
\text { Overall revenues } \\
\text { (\%) }\end{array}$ & 42,26 & 66,40 & 61,82 & 75,09 & 90,01 & 75,34 & 74,44 & 92.2 & 92.7 & $93 * * *$ \\
\hline $\begin{array}{l}\text { Debt service / } \\
\text { GDP (\%) }\end{array}$ & 5,97 & 9,72 & $\mathbf{1 0 , 4 0}$ & 12,99 & 14,76 & 13,68 & 14,60 & 16.9 & 17.2 & \\
\hline
\end{tabular}

* Including the sum of LP 1242 billion owed by the State to the contractors, hospitals...

** During the nine months of the year 2002.

*** Covering the year 2002

Sources: Association of Banks in Lebanon, Annual Reports 1998-2002.

Lebanese Central Bank, Monthly Bulletins, 1998-2003.

\subsection{Public Overborrowing}

The share of the public debt in the GDP reached $182 \%$ in 2002 against $49 \%$ in 1992 . The overrun of the $100 \%$ ceiling in reference to the criteria of the World Bank, the IMF or the Maastricht Agreement is becoming alarming. The question to know whether the Lebanese economy is capable of absorbing this debt volume and rendering it solvable has become very acute since the public debt is increasing at a rhythm superior to that of the GDP. Besides, the slow down in the growth of the Lebanese economy, is probably leading to the aggravation of the crisis causes.

\subsection{The Danger Of Public Debt And The Snowball Effect: Simulation And Modeling}

The analysis ${ }^{15}$ of risks involved in the evolution of the public debt requires elucidating the relation between the public debt rate to the GDP on the one hand, and the inflation rate, the economic growth rate, and the interest rates on public debt on the other hand. This relation can be written as follows:

$\mathrm{d}_{\mathrm{t}}=-[(\mathrm{i}-\mathrm{n}) /(1+\mathrm{n})]^{*} \mathrm{~b}_{\mathrm{t}-1}$

where:

$\mathrm{i}$ is the real interest rate paid on the total public debt $\mathrm{n}$ is the growth rate of the GDP

$b_{t-1}$ is the debt rate to the GDP during the year ${ }_{t-1}$

$\mathrm{d}_{\mathrm{t}}$ is the rate of primary deficit to the GDP during the year $\mathrm{t}$

${ }^{15}$ Klein T. (1994). «External Debt Management: An Introduction » World Bank Technical Paper No.245. Bruton H., et Hill C., (1997). « The Evaluation of Public Expenditure » EDI Learning Ressource Series. 
Table 2- Evolution Of The Public Debt (End Of Period)

\begin{tabular}{|l|c|c|c|c|c|c|c|c|}
\hline In billion LBP & Dec.95 & Dec.96 & Dec.97 & Dec.98 & Dec.99 & Dec.00 & Dec 01 & Sep 02 \\
\hline 1- Total public debt (PD) & 14155 & 20188 & 23503 & 28120 & 33718 & 37643 & 42674 & 46650 \\
\hline Variation \% & 31.1 & 42.6 & 16.4 & 19.9 & 19.9 & 11.6 & 13.4 & 9.3 \\
\hline & & & & & & & & \\
\hline 2- Internal debt & 11997 & 17229 & 19787 & 21686 & 25383 & 27161 & 28214 & 28047 \\
\hline Variation \% & 28.3 & 43.6 & 14.8 & 9.6 & 17.0 & 7 & 3.9 & $(0.6)$ \\
\hline a- Central Bank of Lebanon & 195 & 124 & 375 & 281 & 115 & 1726 & 6251 & 5750 \\
\hline Variation \% & 85.7 & $(36.4)$ & 202.4 & $(25.1)$ & $(59.1)$ & 1400.9 & 262.2 & $(8.0)$ \\
\hline b- Commercial banks & 8453 & 12638 & 13532 & 16133 & 18966 & 18736 & 15830 & 15938 \\
\hline Variation \% & 15.1 & 49.5 & 7.1 & 19.2 & 17.6 & & & \\
\hline c- Other & 3349 & 4467 & 5880 & 5272 & 6302 & 6699 & 6133 & 6359 \\
\hline Variation \% & 76.4 & 33.4 & 31.6 & $(10.3)$ & 19.5 & 6.3 & $(8.4)$ & 3.7 \\
\hline & & & & & & & & \\
\hline 3- Foreign debt & 2158 & 2959 & 3714 & 6434 & 8336 & 10482 & 14460 & 18603 \\
\hline Variation \% & 48.6 & 37.1 & 25.6 & 69.1 & 29.6 & 25.7 & 38.0 & 28.7 \\
\hline & & & & & & & \\
\hline 4- Public sector deposits & 2710 & 3871 & 1406 & 2142 & 4006 & 2631 & 1913 & 1954 \\
\hline Variation \% & 2.8 & 42.8 & $(63.7)$ & 52.3 & 87.0 & $(34.3)$ & $(27.3)$ & 2.1 \\
\hline
\end{tabular}

\begin{tabular}{|l|c|c|c|c|c|c|c|c|}
\hline In percentage & Dec.95 & Dec.96 & Dec.97 & Dec.98 & Dec.99 & Dec.00 & Dec 01 & Sep 02 \\
\hline 1- Total public debt (PD) & 100.0 & 100.0 & 100.0 & 100.0 & 100.0 & 100.0 & 100.0 & 100.0 \\
\hline 2- Internal Debt & 84.8 & 85.3 & 84.2 & 77.5 & 75.3 & 72.2 & 66.1 & 60.1 \\
\hline a- Central Bank & 1.4 & 0.6 & 1.6 & 1.0 & 0.3 & 4.6 & 14.6 & 12.3 \\
\hline b- Commercial Banks & 59.7 & 62.6 & 57.6 & 57.7 & 56.2 & 49.8 & 37.1 & 34.2 \\
\hline c- Other & 23.7 & 22.1 & 25.0 & 18.9 & 18.7 & 17.8 & 14.4 & 13.6 \\
\hline 3- Foreign Debt & 15.2 & 14.7 & 15.8 & 22.5 & 24.8 & 27.8 & 33.9 & 39.9 \\
\hline
\end{tabular}

Source: Central Bank of Lebanon, monthly bulletins (1995-2003)

This equation lays down two possibilities:

1- If $\mathrm{n}>\mathrm{i}$ : The explosion of the debt can be avoided because inflation and growth are enough to stabilize the debt rate to the GDP. Therefore, the government continues to achieve a limited primary deficit that can be covered through indebtedness.

2-If $\mathrm{n}<\mathrm{i}$ : It is the snowball effect, where only interest rates are responsible for the public debt increase. In this case, $\mathrm{d}_{\mathrm{t}}$ is negative, and the government should achieve a primary surplus that can reduce the total amount of the public debt. However, the main difficulty lies in the evaluation of the capacity of governments to achieve a primary surplus in the short run and to adopt fiscal expenditure policies that would enable the achievement of this surplus in the future. However, if these measures sound difficult to implement, the only solution left is to bet on inflation and growth as the means to moderate the volume of the debt.

It appears from what has been stated that the Lebanese financial situation has reached a critical stage where the growth rate of the nominal GDP is inferior to the average interest paid on the public debt. Besides, the total amount of the public debt has exceeded that of the GDP. In order to stabilize the debt, equation (1) should be applied.

We will apply ${ }^{16}$ this equation to the results of the year 1997 and 1998 because during these 2 years we had full access to the required data for the application of our simulation model, unlike other years. However, conclusions

\footnotetext{
${ }^{16}$ It's worth reminding that the main purpose of this model is to illustrate the concept and the application fine points of the snowball effect of the Lebanese public debt in order to build a standard model that can be applied (using the same methodology) to any Third World Country suffering from high public debts.
} 
are still the same for the year 2003 since the public debt is still growing (185\% of the GDP as of September 2003) and all other economic indicators are still the same, not say, deteriorating.

D $98=-(0.1478-0.09 / 1+0.09)$ b97 $=0.01566 \times 1.0597=-0.0562$

Taking into account this equation, and in order to stabilize the share of the public debt, Lebanon had to achieve a primary surplus with a proportion of $5.62 \%$ of the GDP in 1998. In other words, the government had to achieve a surplus of 1.359 billion LP (GDPx5.62\%). However, available figures show that the financial year closed with a primary deficit of 172 billion Lebanese Pounds.

Of course it is not an easy task to get to control the snowball effect. However, the government can succeed if it follows one of the following tracks:

1. Achieve a primary surplus through reducing expenditures (budget austerity, administrative reforms, etc.) and / or through increasing revenues (better tax collection, tax system reform).

2. Bet on increasing the economic growth rate to reduce the difference (then revert it) between nominal growth rate and nominal interest rate on the public debt. It is worth mentioning that increasing the nominal growth rate can be achieved via two ways:

a real revitalization of the national economic growth that would increase budget revenues

b go back to high inflation rates.

A concomitant realization of both options can be observed however.

1. Reduce rates paid on the debt through adopting one of the two following measures:

a Radical modification of the monetary policy in force:

1. Reducing systematic interventions in the money market

2. Increasing money supply.

This strategy can be adopted for the purpose of reducing interest rates on the Lebanese Pound while letting the national currency fluctuating within a determined margin according to the market characteristics. In fact, the objective is to avoid a costly monetary pricing applied independently of real economic facts.

b Restructuring of the public debt:

Conversion of one part of the internal ${ }^{17}$ public debt into an external debt ${ }^{18}$ in view of a direct reduction of the average rate paid on the total debt. Such a reform helps reducing the debt service together with the deficit. It also allows deposits in Lebanese Pounds to have better availability for private local investment. Hence, expected outcomes would be illustrated via a reduction of interest rates on the Lebanese Pound ${ }^{19}$ and via a reduction of public financial expenses ${ }^{20}$. This would eventually promote investment and generate positive growth rates that would enable the State to improve its revenues and accordingly reduce its deficit and its need for additional indebtedness.

\subsection{Assessment Of The Government's Attempt To Restructure The Public Debt In 1998}

In its attempt to restructure the public debt, the government got Parliament approval to finance a part of the 1998 budget deficit with about 2 billion dollars of loans collected on international markets. During 1998, the government borrowed USD 1.450 millions on international markets. These loans were distributed as follows:

\footnotetext{
17 Public debt denominated in Lebanese Pounds.

18 Public debt denominated in foreign currencies.

19 Because of the lower public demand.

${ }^{20}$ Due to the decrease of interest rates.
} 
Table 3 -International Issuance In 1998

\begin{tabular}{|l|c|c|c|c|}
\hline Issuance & Value in million \$/ & Duration (year) & Average revenue \% & Issuing price \\
\hline First issuance & 500 & 3 & 7.38 & 101 \\
\hline Second issuance & 500 & 5 & 8.22 & 100.88 \\
\hline Third issuance & 450 & 7 & 8.79 & 99.25 \\
\hline Total/average & $\mathbf{1 4 5 0}$ & $\mathbf{4 . 9 3}$ & $\mathbf{8 . 1 1}$ & $\mathbf{1 0 0 . 4 2}$ \\
\hline
\end{tabular}

Source: Lebanese Banks Association, Annual Report 1997-1998-1999-2000.

The average interest rate paid on euro-bonds was about $8 \%$ in 1998 with a spread of 3.58 points to American Treasury bonds of the same category. Annual repayments have reached USD 116 millions (8\% x USD 1450 millions), whereas repayments for the same amount of loan denominated in national currency would have been USD 232.6 millions (16.05\% x USD 1.450 millions). Thanks to this interest differential, the Treasury has been able to save USD 116.6 millions. In addition to savings on interest spread, these loans enabled the Government to increase the maturity date of settlement. However, the Government has got to ensure an annual reserve in foreign currencies of about USD 294 millions to be able to settle the loan's principal at the end of the last maturity date.

\subsubsection{Restructuring The Public Debt: Repercussions Of External Debt}

\subsubsection{Action On The Snowball Effect}

Three scenarios are proposed here so as to estimate their impact on debt restructuring at the end of the year 1997:

1. First scenario: primary deficit in 1998 equal to the primary deficit in 1997.

2. $\quad$ Second scenario: primary balance in 1998.

3. Third scenario: primary surplus in 1998.

These scenarios are based on the hypothesis of stabilizing the structure of debts in foreign currencies, which allows the application of the average interest rate (as calculated above) to this debt (i.e. 8\%).

First scenario:

This scenario implies that primary deficit should maintain in 1998 its 1997's level, i.e. 2.025 billion Lebanese Pounds. This level would shift the deficit rate to GDP, d, to $9.38 \%$. Therefore, and based on these hypotheses, we conclude that the theoretical level of the average interest (as calculated in equation 2) susceptible to stabilize the public debt in 1998, while taking into account the estimated level of deficit, is $0.38 \%$, which is impossible.

$0.0838=(\mathrm{i}-0.09 / 1.09) * 1.0597 \Rightarrow \mathrm{i}=0.0038$

Second scenario:

With respect to the second scenario, the equation becomes:

$0=-(\mathrm{i}-0.09 / 1.09)^{*} 1.0597 \Rightarrow \mathrm{i}=0.09$

Thus, the theoretical level of the average interest is supposed to be $9 \%$ in 1998 , so as to make the total debt service equal to 2115 billion Lebanese Pounds, (or 9\% *dt-1) which is the total of the debt at the end of 1997 . The debt structure supposed to be subject to this interest becomes:

$0.1605 x+0.08 y=2.115$ billion Lebanese Pounds

and $x+y=23.501$ 
where

" $x$ " represents the public debt in national currency and

" $y$ " the public debt in foreign currencies (end of 1997).

Therefore, according to (4) and (5)

$\mathrm{x}=\mathrm{LP} 2.919$ billions and

$\mathrm{y}=$ LP 20.585 billions.

In order to stabilize the public debt rate to the GDP with respect to the second scenario, the government should decrease the average interest rate paid on the total public debt to bring it back to $9 \%$. This objective can be reached via an increase in the total external debt to around 20.585 billion Lebanese Pounds, which will lead the external debt's weight to $87 \%$ of the total public debt.

Third scenario:

This scenario implies the realization of a primary surplus of 281 billion Lebanese Pounds, as expected in the 1998 projected budget, which makes the deficit rate related to the GDP equal to $d=-1.162 \%$. In this case equation (1) becomes:

$-0.01162=(\mathrm{i}-0.09 / 1.09) * 1.0597 \rightarrow \mathrm{i}=0.1019$

With respect to an interest rate of $10.19 \%$, a total debt amount of 2.395 billion Lebanese Pounds $(10.19 \% * 23.501)$ should be considered. Hence, the structure of this debt will be as follows:

$0.1605 x+0.08 y=$ LP 2.395 billions

$\mathrm{x}+\mathrm{y}=$ LP 23.504 billions

According to (7) and (8)

$\mathrm{x}=\mathrm{LP} 6.393$ billions and

$\mathrm{y}=\mathrm{LP} 17.111$ billions.

In this perspective, the government needs to reduce the average interest rate to $10.19 \%$ by increasing the total external indebtedness to 17.111 billion Lebanese Pounds, which means converting additional 13.394 billion Lebanese Pounds into foreign currencies debt ${ }^{21}$.

\subsubsection{Limits Of Foreign Indebtedness}

The massive recourse to foreign indebtedness, although it aims at absorbing the financial shock, poses a problem especially when it comes to the part of loans assumed by non-residents.

The World Bank applies a specific model ${ }^{22}$, which is based on a balanced relation between the growth rate of the external debt, exportation, and balance of payments, as shown by the following equation:

$d Z=i-B / D-x$

${ }^{21}$ Which will increase the external debt weight to $73 \%$ of the total debt.

22 Klein T. (1994). «External Debt Management: An Introduction» World Bank Technical Paper No.245. Bruton H., et Hill C., (1997). « The Evaluation of Public Expenditure » EDI Learning Ressource Series. 
where:

"Z" reflects the foreign debt rate or the share of the foreign public debt service in exports, i.e. D/X,

"X" represents exports,

"D" represents the value of the foreign debt service for the period in question. This debt service covers interest and principal repayments.

"dZ" corresponds to the variation of the foreign indebtedness rate Z,

" $\mathrm{i}$ " is the average interest paid on foreign debt,

"x" represents the annual rate of exports growth,

"B" reflects the balance of payments amount at the end of period.

"dZ" defines the sign (or the orientation) of foreign indebtedness rate.

1. When $\mathrm{dZ}$ is negative, the rate of foreign indebtedness tends to decrease,

2. When $\mathrm{dZ}$ is positive, on the contrary, the rate increases.

Foreign indebtedness rate diminishes when:

$\mathrm{i}<\mathrm{x}+\mathrm{B} / \mathrm{D}$

Therefore,

1. If a surplus occurs in the balance of payments - in other words, if $\mathrm{B}>0$ or $\mathrm{B} / \mathrm{D}>\mathrm{O}$ - this ratio can decrease even if the growth rate of exports (value of $x$ ) is inferior to the interest rate $i$, since $x>(i-B) / D$ can be realized.

2. In case of a deficit in the balance of payments - i.e. $\mathrm{B}<0$ - the ratio can only decrease when $\mathrm{x}$ exceeds $\mathrm{i}$ by a value equal to $\mathrm{B} / \mathrm{D}$.

The application of the previous inequation allows to fix the degree of tolerance of the foreign debt. We have applied this model to available financial data for the years 1997 and 1998.

\section{Results of the year 1997}

The following table shows data and hypotheses related to the distribution of the foreign debt over the financial year 1997:

Table 4-Foreign Debt Distribution In 1997

\begin{tabular}{|l|c|c|c|c|c|c|}
\hline & $\begin{array}{c}\text { Value of credits } \\
\text { (in million } \\
\text { dollars) }\end{array}$ & $\begin{array}{c}\text { Average duration } \\
\text { of credits (in } \\
\text { years) }\end{array}$ & $\begin{array}{c}\text { Annual average of } \\
\text { principal repayment } \\
\text { (in million dollars) }\end{array}$ & $\begin{array}{c}\text { Interest on } \\
\text { foreign debt }\end{array}$ & $\begin{array}{c}\text { Annual average } \\
\text { interest (in } \\
\text { million dollars) }\end{array}$ & $\begin{array}{c}\text { Average debt } \\
\text { services on foreign } \\
\text { debt** (in million } \\
\text { dollars) }\end{array}$ \\
\hline Eurobonds & 1050 & 5 & 210 & $8 \%$ & 84 & 294 \\
\hline $\begin{array}{l}\text { Other credits } \\
*\end{array}$ & 1325 & 10 & & $8 \%$ & & 197 \\
\hline $\begin{array}{l}\text { Total foreign } \\
\text { debt }\end{array}$ & 2375 & & & $8 \%$ & & 491 \\
\hline
\end{tabular}

*The average of annual repayments (interest and principal) is calculated on the basis of equal annual total amounts over 10 years.

**The average service of foreign debt is theoretically due and unpaid thus, it must be considered as a provision.

The previous table allows the estimation of the foreign debt service, interest and principal included, as being approximately equal to USD 491 millions in 1997. Moreover, at the end of this year, the surplus in the balance of payments reached USD 420 millions and exports decreased by $12.26 \%$.

Therefore, equation (9) becomes: 
$\mathrm{dZ}=0.08-420 / 491-(-) 0.1226=-0.652$

The surplus in the balance of payments allowed to preserve the negativity of $\mathrm{dZ}$ and conferred to the government a new potential of indebtedness in foreign currencies.

\section{Results of the year 1998}

The following table shows data and hypotheses related to the distribution of the foreign debt over the financial year 1998:

Table 5-Foreign Debt Distribution In 1998

\begin{tabular}{|l|c|c|c|c|c|c|}
\hline & $\begin{array}{c}\text { Value of } \\
\text { credits (in } \\
\text { million } \\
\text { dollars) }\end{array}$ & $\begin{array}{c}\text { Average duration } \\
\text { of credits (in } \\
\text { years) }\end{array}$ & $\begin{array}{c}\text { Annual average of } \\
\text { principal repayment } \\
\text { (in million dollars) }\end{array}$ & $\begin{array}{c}\text { Interest on } \\
\text { the foreign } \\
\text { debt }\end{array}$ & $\begin{array}{c}\text { Annual } \\
\text { average } \\
\text { interest (in } \\
\text { million dollars) }\end{array}$ & $\begin{array}{c}\text { Average debt } \\
\text { service on foreign } \\
\text { debt (in million } \\
\text { dollars) }\end{array}$ \\
\hline Euro-bonds & 2500 & 5 & 500 & $8 \%$ & 200 & 700 \\
\hline Other credits* & 1677 & 10 & & $8 \%$ & & 250 \\
\hline $\begin{array}{l}\text { Total foreign } \\
\text { debt }\end{array}$ & 4177 & & & $8 \%$ & & 950 \\
\hline
\end{tabular}

*The average of annual repayments (interest and principal) is calculated on the basis of equal annual total amounts over 10 years.

**The average service of foreign debt is theoretically due and unpaid thus, it must be considered as a provision.

The service of the foreign debt in 1998 is estimated at USD 950 millions. In addition, the deficit in the balance of payments reached USD 487.6 millions at the end of 1998 and exports increased by $11.18 \%$. Therefore, equation (9) becomes:

$\mathrm{dZ}=0.08+487.6 / 950-0.1118=0.482$

First conclusion: $\mathrm{dZ}$ is positive at the end of 1998. This occurred despite the improvement in the level of exports. Therefore, the potential of foreign indebtedness ${ }^{23}$ has become very limited. It becomes related to the capacity of the economy to achieve a surplus in the balance of payment in order to enable the government repaying the loan.

Considering the case where $\mathrm{dZ}$ is inferior or equal to zero, the growth of exports ( $\mathrm{x}$ ) will be equal to:

$x>0.08+487.6 / 950>0.59$ i.e. $x>i-B / D$

According to equation (12), the growth rate of exports ${ }^{24}$ is supposed to exceed 59\%.

\section{Conclusion}

In the light of the above results, and in order to stop the snowball effect, the stabilization of the public debt requires a restructuring of the public debt where the volume of foreign debt to total debt should fluctuate between 73 and $87 \%$. This objective seems hardly applicable in the current situation given the status of the balance of payments and exports ${ }^{25}$ growth rate.

23 i.e. indebtedness in foreign currencies

${ }^{24}$ It's worth mentioning that Lebanon has systematic recourse to imports in order to cover public and private consumption needs. 25

\begin{tabular}{|l|c|c|c|c|}
\hline In Million \$ & 1999 & 2000 & 2001 & 2002 \\
\hline Balance of trade & -5529 & -5512 & -640 & -3985 \\
\hline Exports & 678 & 713 & 889 & 768 \\
\hline
\end{tabular}


Besides, the major lesson to be drawn from the positive value of $\mathrm{dZ}$ is that the continuation of indebtedness in foreign currency ${ }^{26}$ is not anymore an option towards the stabilization of the debt's share in the GDP. Hence, a massive indebtedness in foreign currencies will expose the national banking sector to multiple risks ${ }^{27}$.

The Lebanese economy shows acute cases of asphyxia and structural imbalances illustrated by: (1) A severe indebtedness crisis resulting from continuous borrowing in order to finance non-productive activities. (2) An intolerable public deficit absorbing a fundamental part of local financial resources. (3) A permanent deficit in the balance of trade that is seriously threatening the balance of payments. This crisis is getting worse and deeper. Therefore, adjusting the situation requires the adoption of a set of reforms dealing with the implementation of a realistic exchange rate, a new structure of interest rates, a fundamental change of the tax system, and a reorganization of the administration far from political interferences.

\section{References}

1. Arestis P. \& Demetriades P. (1997), "Financial Development and Economic Growth: Assessing the Evidence", The Economic Journal, 107(May).

2. $\quad$ Artus P. (1996), Déficits Publics: Théorie et Pratique, Ed. Economica, Paris.

3. $\quad$ Barro R. J. (1984), Macroeconomics, Wiley, New York.

4. $\quad$ Benassy J.P. (1984), Macroéconomie et Théorie du Déséquilibre, Ed. Bordas, Paris.

5. Brillembourg A. (1978). "The Role of Savings in Flow Demand for Money: Alternative Partial Adjustment Models", Staff Paper IMF, 25.

6. Bruton H., and Hill C. (1997), "The Evaluation of Public Expenditure”. EDI Learning Resource Series.

7. Cabannes M. (1998), "Les politiques Conjoncturelles", Economie Synthèse, Armand Colin.

8. Corbet J., et MAYER C. (1991), "Financial Reform in Eastern Europe: Progress with the wrong Model", CEPR Discussion paper no 603.

9. Easterly, Rebelo W. and S. T. (1993), "Fiscal Policy and Economic Growth: An Empirical Investigation", Journal of Monetary Economics 32.

10. Eichengreen B. et Lindert P.H. (1989), "The International Debt Crisis in Historical Perspective", Cambridge, M.A: MIT Press.

11. Fisher S. (1993), "The Role of Macroeconomic Factors in Growth". Journal of Monetary Economics 32, (December 3).

12. Greenwood J. et Jovanovic B. (1990),"Financial Development, Growth and the distribution income", Journal of Political Economy, 18.

13. Gupta K.L. (1992), Budget Deficits and Economic Activity in Asia. Routledge, London.

14. Meier, Gerald M. and Dudley Seers (1984), Pioneers in development, Oxford University Press, New York.

15. Naïmy V. (1996), La Politique Monétaire Au Liban, Université Saint-Joseph, Beirut.

16. Naïmy V. (2003), Marchés émergents, financement des PME et croissance économique: étude du cas libanais, NDU Press.

17. Rosier B. (2000), Les Théories des crises économiques, Ed. La Découverte \& Syros, Paris.

18. Sid A., (1984), Développement sans croissance, l'expérience des économies du tiers-monde, Editions Publisud, Paris.

19. Yachoui E. (2000), “Les Déboires de l’Economie“, An- Nahar, 5 December.

\section{Other Periodicals and Reports}

Lebanese Banks Association: Annual Reports 1992-2002.

Lebanese Banks Association: Monthly review 1998-2003

Central Bank of Lebanon: Monthly Bulletins, 1996-2003.

\footnotetext{
${ }^{26}$ At the end of 2002 , total debt denominated in foreign currencies represented $46.5 \%$ of the total debt. The former reached 22088 billion Lebanese Pounds and the latter 47311 billions.

${ }^{27}$ Mainly the systemic risk.
} 
Notes 